\title{
Expression Analysis of Lily Type Lectin Isotypes in the Rock Bream, Oplegnathus fasciatus: in the Tissue, Developmental Stage and Viral Infection
}

\author{
Young Mee Lee, In Jung Yang, 'Jae Koo Noh, Hyun Chul Kim, Choul-Ji Park, \\ Jong-Won Park, Gyeong Eon Noh, Woo-Jin Kim and Kyung-Kil Kim \\ Genetics and Breeding Research Center, National Institute of Fisheries Science (NIFS), Geoje 53334, Republic of Korea
}

\begin{abstract}
Lectins belong to the pattern-recognition receptors (PRRs) class and play important roles in the recognition and elimination of pathogens via the innate immune system. Recently, it was reported that lily-type lectin-1 is involved when a pathogen attacks in the early immune response of fish. However, this study is limited to information that the lectin is involved in the innate immune response against viral infection. In the present study, the lily-type lectin-2 and -3 of Oplegnathus fasciatus (OfLTL-2 and 3) have been presented to be included B-lectin domain and two D-mannose binding sites in the amino acid sequence that an important feature for the fundamental structure. To investigate the functional properties of OfLTLs, the tissue distribution in the healthy rock bream and temporal expression during early developmental stage analysis are performed using quantitative real-time PCR. OfLTL-2 and 3 are predominantly expressed in the liver and skin, but rarely expressed in other organ. Also, the transcripts of OfLTLs are not expressed during the early developmental stage but its transcripts are increased after immune-related organs which are fully formed. In the challenge experiment with RBIV (rock bream iridovirus), the expression of OfLTLs was increased much more strongly in the late response than the early, unlike previously known. These results suggest that OfLTLs are specifically expressed in the immune-related tissues when those organs are fully formed and it can be inferred that the more intensively involved in the second half to the virus infection.

Key words : Rock bream, Oplegnathus fasciatus, Immune response, Lily type lectin, Gene expression, Rock bream iridovirus (RBIV)
\end{abstract}

\section{INTRODUCTION}

The innate immune system provides a first line of defense against various microorganisms and is essential for the control of pathogenic infections. The adaptive immune system has evolved to provide a more versatile means of defense which prepares increased protection against subsequent reinfection with pathogen. Although the innate immune system cannot always recognize or eliminate infectious pathogens, play a crucial part in the initiation and subsequent direction of adaptive immune responses, as well as participating in the removal of pathogens that have been targeted by an adaptive immune response. Moreover, because there is delay before the initial adaptive immune response takes effect, the innate immune response has a critical role in controlling infections during this period.

The innate immune system is mediated by pattern-recognition receptors (PRRs) that primitive part of the immune system through pathogen-associated molecular patterns (PAMPs) (Magnadóttir, 2006). Lectins belong to the

\footnotetext{
Manuscript received October 19, 2016, Received in revised form November 17, 2016, Accepted December 10, 2016

${ }^{\dagger}$ Corresponding Author : Jae Koo Noh, Genetics and Breeding Research Center, NIFS, Geoje 53334, Republic of Korea. Tel.: +82-55-639-5813, Fax: +82-55-639-5809, E-mail: jae9noh@korea.kr

This is an Open Access article distributed under the terms of the Creative Commons Attribution Non-Commercial License (http:// creativecommons.org/licenses/by-nc/3.0) which permits unrestricted non-commercial use, distribution, and reproduction in any medium, provided the original work is properly cited.
} 
PRR class and a group of sugar binding proteins that recognize the exposed carbohydrates on the cell surface of potential pathogenic microbes, and then agglutinate various cells by binding to cell-surface glycoconjugates (Saraiva et al., 2011). Lectins act as a mediator of self and non-self-recognition and play a significant role in cellular functions, including cell communication, agglutination, proliferation, opsonization, phagocytosis, signal transduction, metastasis and apoptosis (Wassaman et al., 1986; Sharon \& Lis, 2004).

A fish lily-type lectin sequence was identified in snakehead murrel (Channa striata), large yellow croaker (Larimichthys crocea), spotnape ponyfish (Leiognathus nuchalis), bartail flathead (Platycephalus indicus), turbot (Scophthalmus maximus), rock bream (Oplegnathus fasciatus), orange-spotted grouper (Epinephelus coioides) (Arasu et al., 2013; Tasumi et al., 2016). In fish, several articles were published that lectins are involved in the immune response against pathogen infection (Choi et al., 2015; Kim et al., 2011; Park et al., 2012; Thulasitha et al., 2016). However, these studies are limited to information that the lectin is involved in the innate immune response.

The rock bream (Oplegnathus fasciatus) is a commercially important marine fish and it has a high economic value in the South Korea. Although the recent rapid development of the rock bream farming, the spread of bacterial and viral diseases causing enormous economic loss of the aquaculture industry. Rock bream iridovirus (RBIV) is one of the major pathogens in rock bream aquaculture and identified as the most important pathogen infecting rock bream in the last decade (Inouye et al., 1992; Nakajima \& Sorimachi 1994). However, there is little available information based on temporally integrated observations in the immune responses against virus infection. Therefore, research on immunity-related genes in rock bream is necessary to cope with widespread disease infection.
In the previous, OfLTL-1 has been named as RbLTL and reported that changes of expression in the ontogeny, spatial and pathogen infection response (Park et al., 2016). Although the cDNA sequence of the OfLTL-2 and -3 has been reported, no relevant study on the in vivo function of OfLTLs has been conducted. In this study, we investigated that domain analysis and sequence alignment, expression changes in the developmental stage, tissue-specific distribution and expression profile in the immediate and longlasting immune response against RBIV infection.

\section{MATERIALS AND METHODS}

\section{Sequence analysis}

The cDNA and amino acid sequences of OfLTLs were analyzed using the Basic Local Alignment Search Tool (BLAST) at the National Center for Biotechnology Information website (http://blast.ncbi.nlm.nih.gov/Blast.cgi) and the Expert Protein Analysis System (www.expasy.org), as reported previously (Wilkins et al., 1999). Sequence alignment was performed using the ClustalX algorithm (http://www.clustal.org/).

\section{Seedling production for developmental stages} analysis

The brood stock of rock bream (5 years old) were reared in the Genetics and Breeding Research Center of the National Institute of Fisheries Science (NIFS, Geoje, Republic of Korea) with aerated seawater and natural photoperiod in a 30-ton tank. When the water temperature was $23.0 \pm 1.0^{\circ} \mathrm{C}$, photoperiod maintained on a $15 \mathrm{~h}$ light: $9 \mathrm{~h}$ dark to induce the maturation of gonads. After spawned naturally, the fertilized eggs in the same clutch were collected by a blotting silk net and incubated with weak aeration and fresh seawater at $23.5 \pm 0.5^{\circ} \mathrm{C}$. After $25 \mathrm{~h}$, the larvae hatched and were placed in a 15-ton tank at a density of 46 larvae/L. Larvae were fed with the L-type 


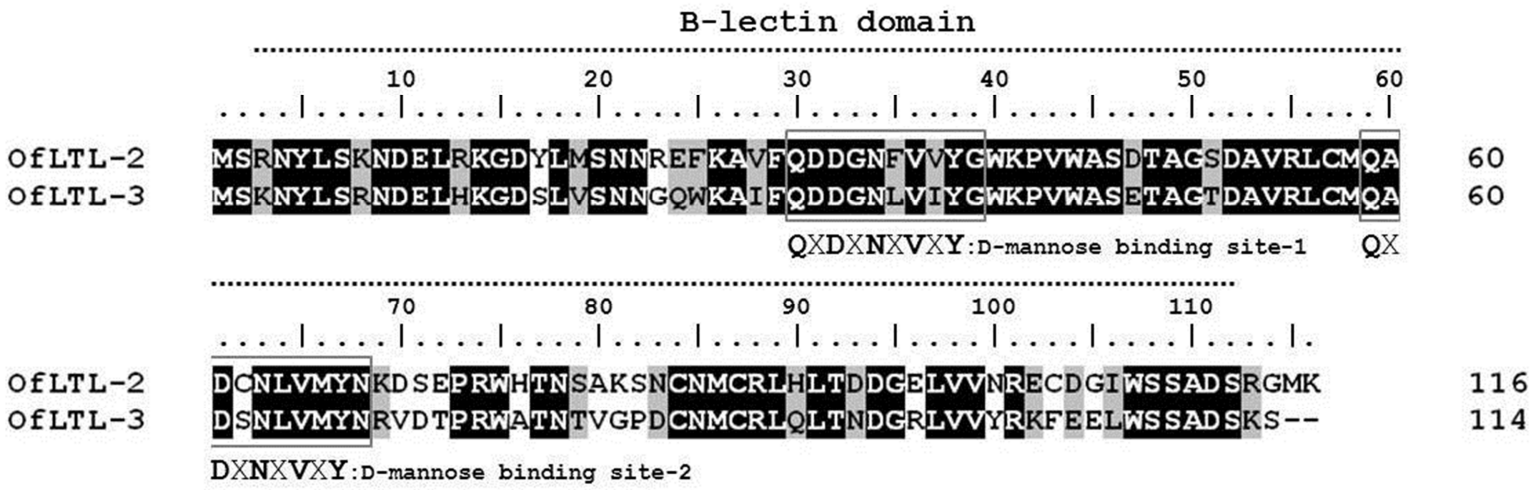

Fig. 1. Sequence alignment of lily type lectins from $\boldsymbol{O}$. fasciatus. The amino acids are numbered along the right margin as well the top of the sequences. The B-lectin domain is indicated by dotted line. Conserved and semi-conserved residues are shaded in black and gray respectively. Deletions are indicated by dashes. The D-mannose binding sites are shown with an empty box. The GenBank accession numbers of lily type lectins are GU565039 (OfLTL-2) and GU565040 (OfLTL-3), respectively. The amino acid sequence homology between the genes is $69.2 \%$.

rotifer Brachionus plicatilis from 3 to 20 days after hatching (DAH) and Artemia nauplii from 16 to $30 \mathrm{DAH}$, and then gradually switched to extruded pellet food beginning at $25 \mathrm{DAH}$. During the rearing time, the rock bream larvae and juveniles were maintained in the conditions as below: water temperature $\left(24.0 \pm 1.0^{\circ} \mathrm{C}\right)$ and salinity $(32.5 \pm 0.5 \%)$.

3. Preparation for tissue distribution and viral challenge experiment

Experimental analysis for tissue distribution including brain, eye, gill, intestine, kidney, liver, skin, spleen and stomach samples were dissected from ten healthy rock breams (total length of approximately $10 \mathrm{~cm}, 5-6$ months old) and immediately frozen in liquid nitrogen, followed by storage in a $-80^{\circ} \mathrm{C}$ freezer until use. The rock breams were anaesthetized prior to experiments involving tissue collection and pathogen injection, and samples were collected under aseptic conditions. Abnormal and diseased fish were excluded in all of the experiments. All fish were acclimatized to experimental condition for 1 week before processing.

For the RBIV challenge experiment, the rock breams were divided randomly into two groups: a control group and a challenged group. The control and challenged fish were injected with $100 \mu \mathrm{L}$ of phosphate buffered saline (PBS) or a RBIV suspension (10 ${ }^{2}$ TCID50 virus/ fish), respectively (Umasuthan et al., 2013). The temperature to which the experimental fish were subjected was controlled at $20^{\circ} \mathrm{C}$ using a re-circulation system, without flow and feeding. Challenged fish collected under aseptic conditions at $0,3,6,12,24$ and 72 hours post-injection and pooled together in equal amounts and frozen in liquid nitrogen. The pooled fish were ground using a homogenizer and subjected to RNA extraction.

\section{Total RNA extraction and cDNA synthesis}

Total RNA was extracted from the ground fish with TRI solution (BSK-Bio Co.) as described in the manufacturer's protocol. The total RNA was treated with DNase-I (SigmaAldrich) to remove genomic DNA contamination. The concentration of total RNA was quantified using spectrophotometrically (BioTek, Gen 5.2) and RNA quality was assessed via electrophoresis in $1 \%$ agarose gels. cDNA was synthesized with SuPrimeScript RT Premix (2X) (GenNet Bio) using an oligo (dT) primer. To syn- 
Table 1. Primer sequences used in this study

\begin{tabular}{cll}
\hline \hline Usage & Primer name & \multicolumn{1}{c}{ Primer sequence (5`-3`) } \\
\hline OfLTL-2 & OfLTL-2 (F) & CTATGGCTGGAAGCCTGTGT \\
& OfLTL-2 (R) & ATCGGTCAGGTGAAGACGAC \\
\multirow{2}{*}{ OfLTL-3 } & OfLTL-3 (F) & GCCGTCTTCAACTGACCAAT \\
& OfLTL-3 (R) & GGGAGGTTAACTGGCTGACA \\
$\beta$-actin & $\beta$-actin (F) & TCATCACCATCGGCAATGAGAGGT \\
& $\beta$-actin (R) & TGATGCTGTTGTAGGTGGTCTCGT \\
\hline
\end{tabular}

thesize cDNA, the reverse transcription reaction was conducted as follows: a mixture containing $1 \mu \mathrm{g}$ of total RNA, the oligo (dT) primer and RNase-free $\mathrm{dH}_{2} \mathrm{O}$ was held at $65^{\circ} \mathrm{C}$ for $5 \mathrm{~min}$, then placed on ice for $5 \mathrm{~min}$. Collect the contents of the tube by brief centrifugation and add $10 \mu \mathrm{L} 2 \mathrm{x}$ SuPrimeScript RT Premix, and then incubates at $60 \mathrm{~min}$ at $50{ }^{\circ} \mathrm{C}$. The final inactivation reaction was carried out for and $10 \mathrm{~min}$ at $70^{\circ} \mathrm{C}$. Specific primers for rock bream lectins and $\beta$-actin were designed using the Primer 3 program (Table 1).

\section{Quantitative real-time PCR}

Expression analysis of rock breams lectins was conducted using quantitative real-time PCR with specific primers, and the mRNA levels of $\beta$-actin were used as an internal control. Quantitative real-time PCR was conducted using the ABI 7500 Real-time Detection System (Applied Biosystems) according to the manufacturer's instructions. The final reaction volume contained $10 \mu \mathrm{L}$ of Fast SYBR Green PCR Master Mix (Applied Biosystems), 100 ng of cDNA, $0.3 \mu \mathrm{L}$ of each of the forward and reverse primers. The amplification procedure consisted of an initial denaturation step for 20 seconds at $95^{\circ} \mathrm{C}$, then 40 cycles of 3 seconds at $95^{\circ} \mathrm{C}$ and 30 seconds at $60{ }^{\circ} \mathrm{C}$, followed by a final dissociation stage. Dissociation curve analysis of the amplification products was performed after quantitative real-time PCR to confirm the specificity of the PCR products.

The relative expression ratio of the target gene versus the $\beta$-actin gene was calculated using the $2-\Delta \Delta C$ t method
(Pfaffl, 2001). All samples were analyzed with three duplicates, and all data are presented in terms of relative mRNA levels, expressed as the mean \pm SE $(n=3)$. Statistical analyses were performed with SPSS 17.0 software (SPSS Inc.) and the data were subjected to one-way analysis of variance (ANOVA). Differences were considered significant at $p<0.05(*)$ and extremely significant at $p<0.01$ $(* *)$.

\section{RESULTS}

\section{Domain motif analysis of OfLTLs}

OfLTLs amino acid sequence do not have a signal peptide nor a trans-membrane region, but contains Bulbtype mannose binding lectin(B-lectin) domain between 3 and 112 aa (total of 110 aa sequence) that typical features for its fundamental structure. A long dimerization interface site is also available within the B-lectin domain profile between aa 4 and 112 (total of 109 aa). The deduced amino acid sequence of rock bream lily type lectin-2 shared 69.2 $\%$ identity with OfLTL-3. OfLTLs two QXDXNXVXY motifs were completely conserved, but third D-mannose binding domain lack in the rock bream.

\section{Developmental stage distributions of OfLTLs transcripts}

To determine whether a role of rock bream lily-type lectins in the early developmental stage, temporal expression analysis was conducted using the samples from immediately after hatching to 60 days larvae and juveniles rock bream fish. For a quantitative analysis, quantitative real-time PCR was carried out using gene-specific primers designed from the OfLTL-2 and 3 coding sequence. Expression of OfLTL-3 was maintained the basal level without substantially increased until $9 \mathrm{DAH}$, and it began to increase from $10 \mathrm{DAH}$ and rapidly was increased up to 60 DAH (Fig. 2B). The overall temporal expression pattern of OfLTL-2 is similar to OfLTL-3, although tran- 


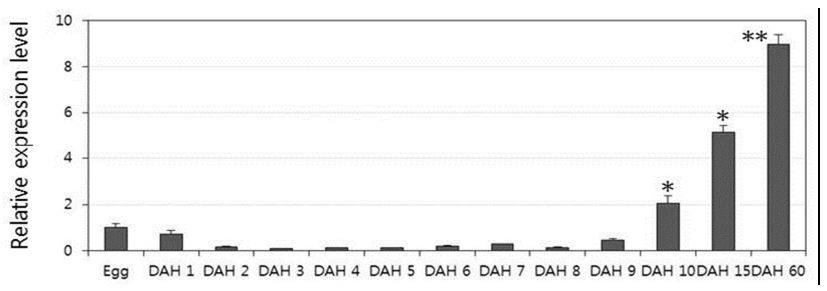

(A)

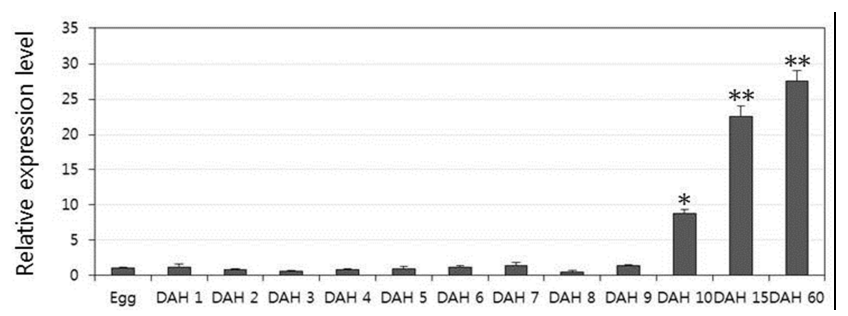

(B)

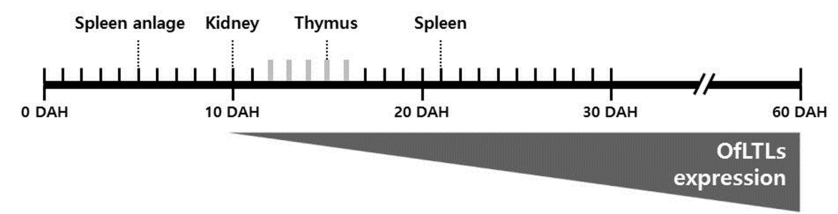

(C)

Fig. 2. Temporal expression analysis of OfLTLs during the early developmental stage of (A) OfLTL-2

(B) OfLTL-3. To investigate the expression pattern of OfLTLs according to the developmental stage, using the sample from fertilization up to 60 days larvae and juveniles rock bream fish. After removing seawater from the sample, soaked in trizol solution and homogenized to extract total RNA. (C) The development scheme of the immune system and expression profile of OfLTLs in the rock bream early developmental stages. Light gray bar shows the bottleneck when many larvae die (12 to $16 \mathrm{DAH}$ ).

sient expression decreased in the early stage that is different with OfLTL-3 (Fig. 2A). In conclusion, OfLTLs are not to expression from the early development, is an increased expression after immune-related organs is fully formed.

\section{Tissue distribution analysis of OfLTLs}

To investigate the role of the rock bream lectins in vivo, it was observed within the tissue distribution. Relative mRNA expression of each tissue was calculated using rock bream $\beta$-actin as a reference gene and the result was further compared with the lowest expression tissue to determine the relative tissue-specific expression profile (set as 1). OfLTL2 and 3 were predominantly expressed in the liver and skin that the highest expression in the skin and the following order was liver. Also, the expression of LTLs was almost at basal level except the liver and skin tissue, although the difference between the high-order depending on the gene (Fig. 3A and B).

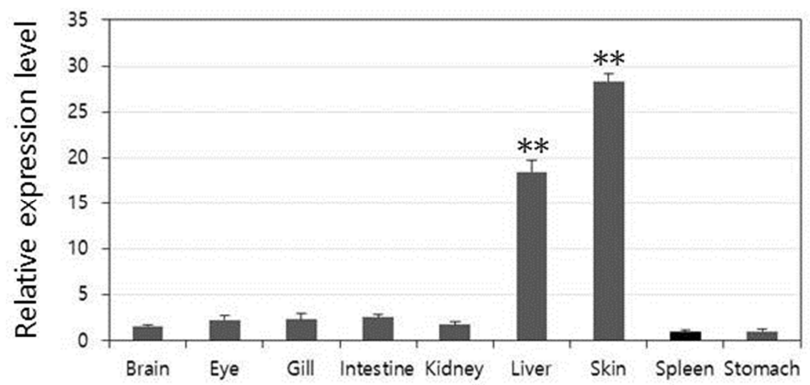

(A)

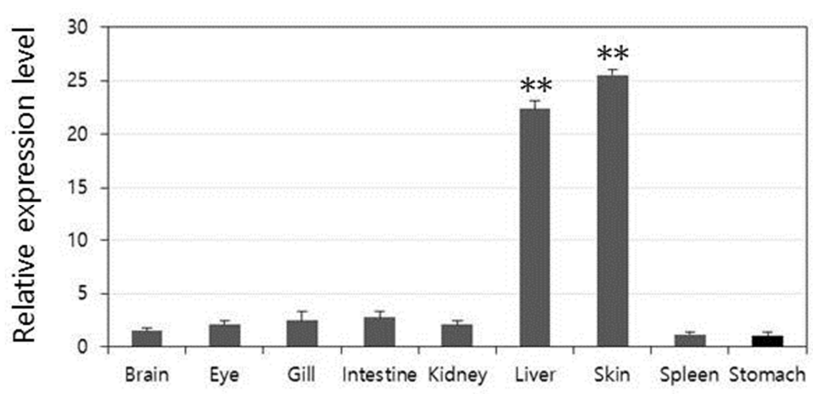

(B)

Fig. 3. mRNA expression of lily type lectins. The spatial distribution of (A) OfLTL-2, (B) OfLTL-3 in various tissues of healthy rock bream fish. The transcript level was determined via quantitative realtime PCR, and rock bream $\beta$-actin was chosen as an internal reference gene. An asterisk indicates a statistically significant difference $* * p<0.01)$ compared with lowest expression the tissue (set as 1, black box). The results are reported as the mean \pm standard deviation (SD) of triplicates. Significance was analyzed via one-way analysis of variance (ANOVA) using the SPSS 17.0 program. 


\section{Expression profiling of OfLTLs after RBIV cha-} llenge

To investigate the function of OfLTLs in the immune response to a viral infection, the temporal patterns of OfLTLs mRNA expression were examined using the whole body of rock bream fish infected with RBIV. Expression patterns and timing are preferentially confirmed with RBIV-induced marker genes to verify a successful challenge experiment. The mRNA level of cathepsin $\mathrm{H}$ expression was high in both the early $(3 \mathrm{H})$ and later stages $(24 \mathrm{H})$; these results are consistent with previous findings (Kim et al., 2013). As shown in Fig. 4, although expression of OfLTL-2 was weak in the early response period, it gradually increased until 24 hours post-infection and then dramatically increased to 72 hours. While, expression of OfLTL-3 maintaining almost the basal levels until 12 hours

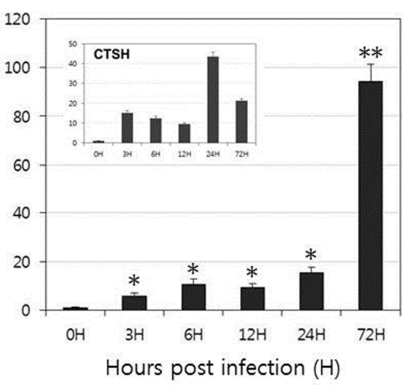

(A)

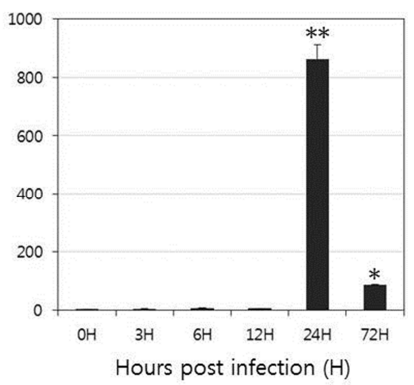

(B)
Fig. 4. The temporal expression pattern of lily type lectins after RSIV infection in the rock bream. The expression patterns of OsLTLs were determined in the whole body (A) OfLTL-2 and (B) OfLTL-3 through quantitative real-time PCR. Cathepsin $\mathrm{H}$ was used as markers to ensure a successful RSIV infection experiment (inset in Fig. 4A). The samples were analyzed at $0,3,6,12,24$ and 72 hours post-injection. The expression of $\beta$-actin was used as internal control for quantitative real-time PCR, and each experiment was performed in triplicate. An asterisk indicates a statistically significant difference $(* p<0.05 ; * * p<0.01)$ compared with $0 \mathrm{~h}$ (set as 1). The results are reported as the mean \pm standard deviation (SD) of triplicates. Significance was analyzed via one-way analysis of variance (ANOVA) using the SPSS 17.0 program. post-infection and it was exponentially in infected 24 hours post-infection, and then increased expression of OfLTL-3 was reduced to $1 / 9$ at 72 hours after infection.

\section{DISCUSSION}

In contrast to higher vertebrates, fish is living in aquatic environments from early embryonic stages of life, which are an ideal medium for microorganism growth compared to air and every moment is constantly exposed to a pathogen attack. The bony fishes are derived from one of the earliest divergent vertebrate lineages to have both innate and acquired immune systems. However, the adaptive immune response did not clearly reveal in fish and it is expected not sophisticated like mammals. Therefore, the innate immune system is the only defense weapons of invertebrates and a fundamental defense mechanism of fish and more dependent their innate immune systems for survival and the resistance to the pathogens.

Lectins play important roles in the recognition and elimination of pathogens via the innate immune system. Researches on the immunological functions of lectin are concentrated in the innate immune response of higher vertebrates. However, our results seem to be involved both in the innate and adaptive immune response; lily-type lectins are expressed after completing immune system during early developmental stage and preferentially increased in the second half reaction in a viral challenge, these results are related to the adaptive immune response. On the other side, OfLTLs are expressed in the innate immune response related tissue. Because fish have not sophisticated and specialized the adaptive immune systems, the innate immunity-related genes will be able to engage in the longlasting immune responses to infection. Research findings are not infrequently has been reported that the early and late results are quite cross. Therefore, outside the framework defined in the higher vertebrates various studies will be needed. 
In the development of the immune system rock bream, spleen anlage was observed between the swim bladder and the intestine at $5 \mathrm{DAH}$, and the thymus was formed as a paired structure under the pharyngeal epithelium above the gill arch at $10 \mathrm{DAH}$. The order of the immune organs becoming lymphoid was the pronephric kidney (10 DAH), thymus (15 DAH) and spleen (21 DAH) (Zhizhong et al., 2013). OfLTLs were hardly expressed in the initial developmental phase and increased from $10 \mathrm{DAH}$. Thereafter, expression of OfLTLs was proportionate to development of rock bream immune organ. It can be inferred that they will participate in the immune response after the immune system is fully established, not involved from the initial development period.

Fish are permanently exposed to various external hazards that aerobic and anaerobic bacteria, viruses, parasites, marine pollutants. To protect fish from pathogenic microorganisms, mucus acts as a physical, chemical and biological barrier between the fish and the environment which first site of interaction with pathogens. The mucus composition is very complex and includes immuneglobulins, agglutinins, lectins, lysins and lysozymes that are anti-microbial factor and is secreted from the fish skin. These factors are very important recognize the microorganisms invasion and to protect the fish from invading pathogens (Lee et al., 2015; Suzuki et al., 2003).

The liver is unique anatomical and immunological organ: The typical function of the liver is carbohydrate, protein and lipid metabolism, bile secretion, antioxidation and detoxification. As well as, the liver play a critical roles against invading pathogen in the innate immune responses of fish that particularly enriched macrophages and lymphocytes compared with other organs and modulated of liver injury and recruitment of circulating lymphocytes (Racanelli \& Rehermann, 2006; Castro et al., 2014).

Although it does not clearly separated innate and acquired immune response dedicated organ in fish, liver and skin are primarily involved in many innate immune response. In this study, OfLTLs are predominantly expressed in the liver and skin. These results are to be expected that OfLTLs contribute to the innate immune response against viral infection, but the transcripts were increased to more intensively in the period of acquired immune of RBIV challenge experiments. For this reason, the further expression analysis is needed using a virus-infected liver and skin tissue of the fish because it uses the RSV infection whole fish in this experiment.

\section{ACKNOWLEDGEMENTS}

This work was supported by a grant from the National Institute of Fisheries Science (R2016001).

\section{REFERENCES}

Arasu A, Kumaresan V, Sathyamoorthi A, Palanisamy R, Prabha N, Bhatt P, Roy A, Thirumalai MK, Gnanam AJ, Pasupuleti M, Marimuthu K, Arockiaraj J (2013) Fish lily type lectin-1 contains $\beta$-prism architecture: Immunological characterization. Mol Immunol 56:497-506.

Castro R, Abós B, Pignatelli J, von Gersdorff Jørgensen L, González Granja A, Buchmann K, Tafalla C (2014) Early immune responses in rainbow trout liver upon viral hemorrhagic septicemia virus (VHSV) infection. PLoS One 22:e111084.

Choi KM., Shim SH, An CM, Nam BH, Jeong JM, Kim JW, Park CI (2015) Functional characterisation and expression analysis of recombinant serum amyloid $\mathrm{P}$ isoform 1 (RbSAP1) from rock bream (Oplegnathus fasciatus). Fish Shellfish Immunol 45:277-285.

Inouye K, Yamano K, Maeno Y, Nakajima K, Matsuoka M, Wada Y, Sorimachi M (1992) Iridovirus infection of cultured red sea bream, Pagrus major. Fish Pathol 27:19-27.

Kim BS, Nam BH, Kim JW, Park HJ, Song JH, Park CI 
(2011) Molecular characterisation and expression analysis of a fish-egg lectin in rock bream, and its response to bacterial or viral infection. Fish Shellfish Immunol 31:1201-1207.

Kim JW, Park CI, Hwang SD, Jeong JM, Kim KH, Kim DH, Shim SH (2013) Molecular characterisation and expression analysis of the cathepsin $\mathrm{H}$ gene from rock bream (Oplegnathus fasciatus). Fish Shellfish Immunol 35:188-194.

Lee JW, Kim JE, Goo IB, Hwang JA, Im JH, Choi HS, Lee JH (2015) Expression of immune-related genes during loach (Misgurnus anguillicaudatus) embryonic and early larval development. Dev Reprod 19:181-187. Magnadóttir B (2006) Innate immunity of fish (overview). Fish Shellfish Immunol 20:137-151.

Nakajima K, Sorimachi M (1994) Biological and physicochemical properties of the iridovirus isolated from cultured red sea bream, Pagrus major. Fish Pathol 29:29-33.

Park HJ, Kim JW, Kim EG, Kim HN, Chae YS, Jeong JM, Kim DH, Park CI (2012) Molecular cloning and expression analysis of two distinct F-type lectins from the rock bream, Oplegnathus fasciatus. Dev Comp Immunol 36:230-235.

Park HJ, Jeong JM, Bae JS, Kim JW, An CM, Min BH, Kim SY, Myeong JI, Hwang HK, Park CI (2016) Molecular cloning and expression analysis of a new lily-type lectin in the rock bream, Oplegnathus fasciatus. Dev Comp Immunol 65:25-30.

Pfaffl MW (2001) A new mathematical model for relative quantification in real-time RT-PCR. Nucleic Acids Res 29:e45.

Racanelli V, Rehermann B (2006) The liver as an immunological organ. Hepatology 43:54-62.

Saraiva TC, Grund LZ, Komegae EN, Ramos AD, Conceição K, Orii NM, Lopes-Ferreira M, Lima C (2011) Nattectin a fish C-type lectin drives Th1 responses in vivo: licenses macrophages to differrentiate into cells exhibiting typical DC function. Int Immunopharmacol 11:1546-1556.

Sharon N, Lis H (2004) History of lectins: from hemagglutinins to biological recognition molecules. Glycobiology 4:53-62.

Suzuki Y, Tasumi S, Tsutsui S, Okamoto M, Suetake H (2003) Molecular diversity of skin mucus lectins in fish. Comp Biochem Physiol B Biochem Mol Biol 136:723-730.

Tasumi S, Yamaguchi A, Matsunaga R, Fukushi K, Suzuki Y, Nakamura O, Kikuchi K, Tsutsui S (2016) Identification and characterization of pufflectin from the grass pufferfish Takifugu niphobles and comparison of its expression with that of Takifugu rubripes. Dev Comp Immunol 59:48-56.

Thulasitha WS, Umasuthan N, Whang I, Nam BH, Lee J (2016) Antimicrobial response of galectin-1 from rock bream Oplegnathus fasciatus: Molecular, transcripttional, and biological characterization. Fish Shellfish Immunol 50:66-78.

Umasuthan N, Revathy KS, Bathige SD, Lim BS, Park MA, Whang I, Lee J (2013) A manganese superoxide dismutase with potent antioxidant activity identified from Oplegnathus fasciatus: genomic structure and transcriptional characterrization. Fish Shellfish Immunol 34:23-37.

Wassaman PM, Bleil JD, Florman HM, Greve JM, Roller RJ, Salzmann GS (1986) Nature of the mouse egg's receptor for sperm. Adv Exp Med Biol 207:55-77.

Wilkins MR, Gasteiger E, Bairoch A, Sanchez JC, Williams KL, Appel RD, Hochstrasser DF (1999) Protein identification and analysis tools in the ExPASy server. Methods Mol Biol 112:531-552.

Zhizhong X, Tao H, Jun L, Tianxiang G (2013) Ontogeny of the immune system in rock bream Oplegnathus fasciatus. Chin J Oceanol Limnol 31:1028-1035. 